\title{
Cloning and analysis of antiviral activity of a barramundi (Lates calcarifer) Mx gene
}

\author{
Y.C. Wu, S.C. Chi* \\ Institute of Zoology and Department of Life Science, National Taiwan University, 1, Sec. 4, Roosevelt Rd., Taipei 10617, Taiwan, ROC
}

Received 25 July 2006; revised 26 September 2006; accepted 26 September 2006

Available online 4 October 2006

\begin{abstract}
We obtained a full-length cDNA clone for the Mx gene of barramundi (Lates calcarifer), using RACE (rapid amplification of cDNA ends) polymerase chain reaction (PCR) amplification of RNA extracted from a barramundi brain cell line cBB. The Mx cDNA of $2.2 \mathrm{~kb}$ contains an open reading frame (ORF) of 1875 nucleotides encoding a protein of 624 amino acids. The predicted barramundi Mx protein is $71.4 \mathrm{kDa}$ and contains a tripartite guanosinetriphosphate (GTP)-binding motif at the amino terminal and a leucine zipper at the carboxyl terminal, characteristic of all known Mx proteins. Poly I:C-transfection induced the expression of $\mathrm{Mx}$ gene in cBB cells, and the induction level at $28{ }^{\circ} \mathrm{C}$ was higher than that at $20^{\circ} \mathrm{C}$. Moreover, Mx gene expression was also induced by viral infection, including fish nodavirus, birnavirus, and iridovirus. Among these, nodavirus was a stronger inducer than the other two viruses. Using an antiviral activity assay, we revealed that poly I:C-transfected cBB cells had antiviral activity against fish nodavirus and birnavirus, but not iridovirus. Furthermore, the replication of nodavirus and birnavirus could be restored after the expression of Mx gene was down-regulated by siRNA. Therefore, these results indicated that the expression of barramundi Mx gene was able to inhibit the proliferation of fish nodavirus and birnavirus.
\end{abstract}

(C) 2006 Elsevier Ltd. All rights reserved.

Keywords: Mx; Barramundi; cBB cell line; Poly I:C; Nodavirus; Birnavirus; Iridovirus

\section{Introduction}

The type I interferon (IFN) system is one of the most important mechanisms for antiviral defense. In the type I IFN response, many IFN-related proteins are induced for establishing an antiviral state, such as double-stranded RNA-activated protein kinase (PKR), the 2', 5'-oligoadenylate synthetase, and Mx proteins [1]. Mx proteins belong to the dynamin superfamily [2] and contain a tripartite GTP-binding domain essential for the antiviral activity [3]. The first Mx protein was found in mice and named because of its resistance to orthomyxovirus influenza A [4]. Mx genes were subsequently found in higher vertebrates, including human [5], some livestock species [6-8], and birds [9,10]. Moreover, some Mx proteins have been shown to inhibit virus replication [11-14].

\footnotetext{
it Statement: The corresponding author (Dr. Chi S.C.) has signed permission from another author (Wu Y.C.) to act on their behalf.

* Corresponding author. Tel.: +88623366 2505; fax: +8862 23673852 .

E-mail address: shauchi@ccms.ntu.edu.tw (S.C. Chi).
} 
The lack of information on fish IFN and the difficulty of IFN detection due to its small production and short halflife, led to the use of Mx gene expression as an indicator of IFN activity. Until now, Mx remains useful as a sensitive and more stable marker of the IFN response. In fish, the first Mx gene was identified from perch (Perca fluviatilis L.) [15]. Following, piscine Mx genes have been cloned and characterized in rainbow trout (Oncorhynchus mykiss Walbaum) [16], Atlantic salmon (Salmo salar L.) [17], Atlantic halibut (Hippoglossus hippoglossus L.) [18], Japanese flounder (Paralichthys olivaceus) [19], fugu (Takifugu rubripes) [20], gilthead sea bream (Sparus aurata) [21], channel catfish (Ictalurus punctatus) [22], and orange-spotted grouper (Epinephelus coioides) [23]. However, only few papers have demonstrated the role of fish Mx proteins in IFN response. For example, the Japanese flounder Mx can inhibit the replication of hirame rhabdovirus and viral hemorrhagic septicemia virus (VHSV) [24], while the Atlantic salmon Mx1 can inhibit the replication of infectious pancreatic necrosis virus (IPNV) [25].

Fish nodavirus, nervous necrosis virus (NNV), and fish iridovirus are two major viral pathogens among many species of cultured marine fish in Taiwan [26,27]. The mortality of NNV-infected fish at the larval stage could be as high as $80-100 \%$, and most of the survivors became persistently infected [28]. The information about the mechanism of NNV persistent infection has been very limited until the NNV-persistently infected cell line BB was established [29], and a negative control cell line cBB was obtained by treating BB cells with NNV-specific antiserum [30]. Mx mRNA was detected in the BB cells, but not in the NNV-free cBB cells. In the present study, a barramundi Mx cDNA was cloned from the cBB cells, and the expression of Mx gene in cBB cells was analyzed after poly I:C transfection and virus infection. The antiviral activities against fish nodavirus, birnavirus and iridovirus in poly I:C-transfected cBB cells were examined, and the level of viral replication was further analyzed in cBB cells whose Mx gene expression was down-regulated by siRNA.

\section{Materials and methods}

\subsection{Cell lines and viruses}

The cBB cells were cultured with L-15 medium supplemented with $10 \%$ fetal bovine serum (FBS), and incubated at $28{ }^{\circ} \mathrm{C}$. Three fish viruses used in the study were: (1) fish nodavirus, B00GD, an NNV isolate of infected barramundi [26]; (2) fish birnavirus, IPNV-SP; and (3) fish iridovirus, TGIV, an isolate from infected grouper [27]. The GF-1 (Grouper Fin-1) cell line [31], the RTG-2 cell line, and the GF-3 (Grouper Fin-3) cell line were respectively used for nodavirus, birnavirus, and iridovirus proliferation and titration.

\subsection{Cloning of a barramundi Mx cDNA fragment}

A primer set, which was designed from the rainbow trout Mx [16] and channel catfish Mx [22] was chosen to amplify a fragment of the barramundi $\mathrm{Mx}$ gene. The sequence of forward primer was $5^{\prime}$-TGAGG AGAAGGTGCGTCC- $3^{\prime}$ and that of reverse primer was 5'-CTTCTGACCCCTGCACCTGACGA- ${ }^{\prime}$. The acid guanidinium thiocyanate-phenol-chlorofrom extraction method [32] was used to extract the total RNA from the cBB cells, which were infected with NNV (B00GD) (MOI = 5) for 2 days. Reverse transcription was carried out by incubating $1 \mu \mathrm{g}$ total RNA at $42{ }^{\circ} \mathrm{C}$ for $1 \mathrm{~h}$ in $30 \mu \mathrm{l} 1 \mathrm{X}$ reaction buffer containing $0.3 \mu \mathrm{M}$ oligo(dT) $)_{20}, 0.4 \mathrm{mM} \mathrm{dNTP}, 11.7 \mathrm{mM}$ DTT, $40 \mathrm{U}$ ribonuclease inhibitor rRNasin (Promega), and $60 \mathrm{U}$ MMLV reverse transcriptase (Promega). For PCR reaction, an aliquot $(5 \mu \mathrm{l})$ of the cDNA was amplified in final volume of $25 \mu \mathrm{l}$ standard 1X PCR buffer containing $0.4 \mu \mathrm{M}$ forward and reverse primer, $0.25 \mathrm{mM} \mathrm{dNTP}$, and $0.5 \mathrm{U}$ DyNazyme II DNA polymerase (Finnzymes). The PCR was carried out in GeneAmp PCR System 2400 (Applied Biosystems) with a denaturing step of $94{ }^{\circ} \mathrm{C}$ for $3 \mathrm{~min}$, followed by 30 cycles of $94{ }^{\circ} \mathrm{C}$ for $30 \mathrm{~s}, 60{ }^{\circ} \mathrm{C}$ for $30 \mathrm{~s}$, and $72{ }^{\circ} \mathrm{C}$ for $45 \mathrm{~s}$, with a final extension of $72{ }^{\circ} \mathrm{C}$ for 5 min. A 718 bp PCR product was cloned into pGEM-T easy vector (Promega) and sequenced.

\subsection{RACE cloning of the full-length barramundi Mx cDNA}

RACE was carried out using the Generacer ${ }^{\mathrm{TM}}$ primers (Invitrogen), including $5^{\prime}$ RACE Abridged Anchor Primer (AAP), 3' RACE Adapter Primer (AP) and Abridged Universal Amplification Primer (AUAP). The genespecific primers (gsp) used in the RACE were designed from the $718 \mathrm{bp}$ fragment sequence of barramundi Mx obtained in Section 2.2, including 5' RACE first gsp (5'-GCGCCTCCAACACGGAGCTC-3'), 5' RACE second gsp 
(5'-CAGCGCCAGGTCCTTCTCCAC-3'), 3' RACE first gsp (5'-CAGGATGAAATGGCCGGGGTTGGTGTGG-3'), $3^{\prime}$ RACE second gsp (5'-CACAGAGGCTTTGAAGATGGCACAGGAG-3'). Both $5^{\prime}$ and $3^{\prime}$ RACE were performed on the total RNA extracted from cBB cells, which were infected with NNV (B00GD) (MOI $=1)$ for 2 day.

For 5' RACE, $24 \mu \mathrm{g}$ total RNA of NNV-infected cBB cells were transcribed into cDNA using 5' RACE first gsp. The cDNA was then purified by PCR-M Clean Up System (Viogene) and eluted with $25 \mu$ l deionized-distilled water. A poly (C) tail was synthesized onto the ends of the cDNA $(9 \mu \mathrm{l})$ with $5 \mathrm{U}$ terminal transferase (Biolabs) in $25 \mu \mathrm{l}$ reaction buffer $\left(1 \times\right.$ NEBuffer $\left.4,0.25 \mathrm{mM} \mathrm{CoCl}_{2}, 0.2 \mathrm{mM} \mathrm{dCTP}\right)$ incubating at $37{ }^{\circ} \mathrm{C}$ for $30 \mathrm{~min}$, and the reaction was stopped by heating at $95^{\circ} \mathrm{C}$ for $5 \mathrm{~min}$. An aliquot $(5 \mu \mathrm{l})$ of the poly $(\mathrm{C})$ tailed cDNA was amplified by PCR using $5^{\prime}$ RACE AAP and 5' RACE first gsp. The nested PCR was amplified with AUAP and 5' RACE second gsp. The PCR program was as same as that in Section 2.2. A 224 bp PCR product was cloned into the pGEM-T easy vector (Invitrogen) and sequenced.

For $3^{\prime}$ RACE, $6 \mu \mathrm{g}$ total RNA was transcribed into cDNA with $3^{\prime}$ RACE AP. An aliquot $(5 \mu \mathrm{l})$ of the cDNA was amplified by PCR with $3^{\prime}$ RACE first gsp and AUAP. The PCR reaction was performed by an initial denaturing step of $94{ }^{\circ} \mathrm{C}$ for $3 \mathrm{~min}$, followed by 5 cycles of $94{ }^{\circ} \mathrm{C}$ for $30 \mathrm{~s}, 72{ }^{\circ} \mathrm{C}$ for $2 \mathrm{~min} 30 \mathrm{~s}$, and 5 cycles of $94{ }^{\circ} \mathrm{C}$ for $30 \mathrm{~s}, 70{ }^{\circ} \mathrm{C}$ for $30 \mathrm{~s}, 72{ }^{\circ} \mathrm{C}$ for $2 \mathrm{~min}$, and 25 cycles of $94{ }^{\circ} \mathrm{C}$ for $30 \mathrm{~s}, 68{ }^{\circ} \mathrm{C}$ for $30 \mathrm{~s}, 72{ }^{\circ} \mathrm{C}$ for $2 \mathrm{~min}$, with a final extension of $72{ }^{\circ} \mathrm{C}$ for $5 \mathrm{~min}$. The nested PCR amplified with $3^{\prime}$ RACE second gsp and AUAP. The nested PCR reaction was performed by an initial denaturing step of $94{ }^{\circ} \mathrm{C}$ for $3 \mathrm{~min}$, followed by 30 cycles of $94{ }^{\circ} \mathrm{C}$ for $30 \mathrm{~s}$, $65{ }^{\circ} \mathrm{C}$ for $30 \mathrm{~s}, 72{ }^{\circ} \mathrm{C}$ for $2 \mathrm{~min}$, with a final extension of $72{ }^{\circ} \mathrm{C}$ for $5 \mathrm{~min}$. A $1526 \mathrm{bp}$ PCR product was cloned into the pGEM-T easy vector (Invitrogen) and sequenced. The $5^{\prime}$ and $3^{\prime}$ RACE sequence overlapped the $718 \mathrm{bp}$ fragment sequence of barramundi Mx by $76 \mathrm{bp}$ and $178 \mathrm{bp}$, respectively.

Mx amino acid sequences of different species were aligned using Clustal W, and a phylogenetic tree (neighborjoining) was carried out using MEGA3 [33], with bootstrapping values taken from 1000 replicates.

\subsection{Mx expression in $c B B$ cells induced by poly I:C transfection or fish virus infection}

The cBB cells were seeded in $30 \mathrm{~mm}$ cultured dishes $\left(2 \times 10^{5}\right.$ cells per dish). On the second day, cells were transfected with poly I:C $\left(1 \mu \mathrm{g} \mathrm{ml}^{-1}\right)$ using lipofectin (Invitrogen), or individually infected with fish nodavirus (B00GD), fish birnavirus (IPNV-SP), and fish iridovirus (TGIV) $(\mathrm{MOI}=10)$. Total cellular RNA was extracted at 0, 6, 12, 24, 48, $72 \mathrm{~h}$ post transfection or infection, and $1 \mu \mathrm{g}$ of total RNA was then transcribed into cDNA with oligo $(\mathrm{dT})_{20}$ described as above.

Real-time PCR was conducted to determine the level of Mx gene expression in the poly I:C-transfected or virusinfected cells over the control. Primers for Mx were forward primer $5^{\prime}$-TGAGGAGAAGGTGCGTCC-3' and reverse primer $5^{\prime}$-GCGCCTCCAACACGGAGCTC-3'. Actin was used as an internal control, and primers of actin were forward primer 5'-CACTCAACCCCAAAGCCAACAGG-3' and reverse primer 5'-AAAGTCCAGCGCCACGTAG CACAG- $3^{\prime}$ [25]. An aliquot $(0.5 \mu \mathrm{l})$ of the cDNA was analyzed with PCR mixture in atot volume of $20 \mu \mathrm{l}$ containing $0.5 \mu \mathrm{M}$ forward primer and reverse primer in $1 \mathrm{X}$ iQ SYBR Green SuperMix (Bio-Rad). The amplification was carried out in iCycler iQ Real-Time PCR Detection System (Bio-Rad) with an initial denaturing step of $94{ }^{\circ} \mathrm{C}$ for $3 \mathrm{~min}$, followed by 40 cycles of $94{ }^{\circ} \mathrm{C}$ for $20 \mathrm{~s}, 60^{\circ} \mathrm{C}$ for $20 \mathrm{~s}, 72{ }^{\circ} \mathrm{C}$ for $20 \mathrm{~s}$, and fluorescence detection at $85^{\circ} \mathrm{C}$ for $20 \mathrm{~s}$. All samples were analyzed in triplicate. The Mx expression levels were normalized with internal control (actin), and the normalized Mx expression value of the negative control without poly I:C transfection or virus infection was regarded as 1 .

\subsection{Antiviral activity assay}

The optimal multiplicity of infection (MOI) of each virus capable of inducing complete cytopathic effect (CPE) of cBB cells was determined and applied in the following experiment.

The cBB cells were pre-seeded in a 96-well tissue culture plate $\left(1 \times 10^{4}\right.$ cells per well $)$, and transfected with poly $\mathrm{I}: \mathrm{C}\left(1 \mu \mathrm{g} \mathrm{ml}^{-1}\right)$ on the second day. Control cells were mock-transfected. After $24 \mathrm{~h}$ incubation, supernatants were removed from cBB cells, and the cells were washed 3 times in phosphate buffered saline (PBS). Then, every 4 wells as a group was infected with fish nodavirus $(\mathrm{B} 00 \mathrm{GD})(\mathrm{MOI}=100)$, fish birnavirus (IPNV-SP) $(\mathrm{MOI}=0.1)$, and fish iridovirus (TGIV) $(\mathrm{MOI}=10)$, respectively. 
After the appearance of complete CPE in the wells of control cells, the entire 96-well plate was stained by crystal violet $(0.5 \%$ in methanol) for $30 \mathrm{~min}$. Then, the plate was washed in tap-water and air-dried. The optical density (OD) of each well was measured at $595 \mathrm{~nm}$ using an ELISA reader (MRXplus, DYNEX Technologies). The highest $\mathrm{OD}_{595}$ values appeared in the wells of cBB cells without viral infection (non-infected control). The relative survival rate of $\mathrm{cBB}$ cells after each virus infection was calculated with the formula: (the average $\mathrm{OD}_{595}$ value from 4 wells of virus-infected cells/the average $\mathrm{OD}_{595}$ value from 4 wells of the non-infected cells) $\times 100 \%$.

\subsection{The influence of Mx gene expression on the replication of fish virus}

The cBB cells pre-seeded in 24-well-plates $\left(4 \times 10^{4}\right.$ cells per well) were transfected with a mixture of four barramundi Mx-specific siRNAs (100 nM) or $100 \mathrm{nM}$ non-silencing control siRNA (QIAGEN) as negative control, and then transfected with poly I:C $\left(25 \mathrm{ng} \mathrm{ml}^{-1}\right) 4 \mathrm{~h}$ later. After $18 \mathrm{~h}$, total RNA of the cells was extracted for realtime PCR and analyzed for the Mx gene expression. The treated-cells were also infected with nodavirus, birnavirus, and iridovirus, respectively. The cells were washed with PBS $1 \mathrm{~h}$ post virus adsorption, and incubated at $28^{\circ} \mathrm{C}$ for nodavirus and iridovirus replication or $20^{\circ} \mathrm{C}$ for birnavirus replication. After $24 \mathrm{~h}$, the infected cells were harvested and frozen-thawed 3 times for progeny virus titration. The sense sequences of the Mx-specific siRNAs are Mx-1 r(AGAUGGAGAUGAUCGUUUA)dTdT, Mx-2 r(GCUUCAUUGGAUUUCCUAA)dTdT, Mx-3 r(GACAAAGAU CGAAGCCAUA)dTdT, Mx-4 r(AGCUGAUGUUACACCUUAA)dTdT, and the sense sequence of the non-silencing control siRNA is r(UUCUCCGAACGUGUCACGU)dTdT.

\section{Results}

\subsection{Sequence analysis of the barramundi Mx gene}

The $5^{\prime}$ and $3^{\prime}$ RACE sequence overlapped the $718 \mathrm{bp}$ fragment of barramundi Mx gene sequence by $76 \mathrm{bp}$ and $178 \mathrm{bp}$ respectively. The three parts of the sequences were aligned to give a full length cDNA sequence of $2214 \mathrm{bp}$, which contains an ORF of $1875 \mathrm{bp}$, encoding a 624 amino acid polypeptide with a predicted molecular weight of $71.4 \mathrm{kDa}$. The amino terminal contains a tripartite GTP-binding motif and a dynamin family signature. The carboxyl terminal contains a putative leucine zipper motif conserved in all other Mx proteins (Fig. 1). The Genebank accession number of barramundi Mx sequence is AY821518.

\subsection{Comparison of barramundi Mx protein with other Mx proteins}

The results of the BLAST analysis using the deduced amino acid sequence of the barramundi Mx protein are shown in Table 1. Barramundi Mx showed highest homology with grouper Mx (87\% identity), followed by Japanese flounder Mx (85\% identity). Of the non-teleost Mx, barramundi Mx showed 56\% identity with human MxA. The Clustal W alignment of the deduced barramundi Mx amino acid sequence with other known fish Mx is shown in Fig. 1, and the highest similarity was located in the amino terminals of the Mx proteins. Subsequently, a neighbor-joining tree comparing all the fish Mx, using human MxA and duck Mx as outgroups, revealed that the barramundi Mx belongs to the cluster of fugu, sea bream, grouper, Japanese flounder, and Atlantic halibut Mx (Fig. 2).

\subsection{Induction of Mx expression by poly I:C transfection}

Poly I:C-transfected cBB cells were incubated either at 28 or $20^{\circ} \mathrm{C}$, and the time course expression of Mx was detected by real-time PCR. When poly I:C-transfected cBB cells were incubated at both 28 and $20^{\circ} \mathrm{C}, \mathrm{Mx}$ gene expression peaked at $24 \mathrm{~h}$ post-transfection, and decreased thereafter. Moreover, the overall $\mathrm{Mx}$ gene expression at $28^{\circ} \mathrm{C}$ was higher than that at $20^{\circ} \mathrm{C}$. At the point of their highest expression ( $24 \mathrm{~h}$ post-transfection), the level of Mx gene expression at $28^{\circ} \mathrm{C}$ was 4 -fold higher than that at $20^{\circ} \mathrm{C}$ (Fig. 3). 


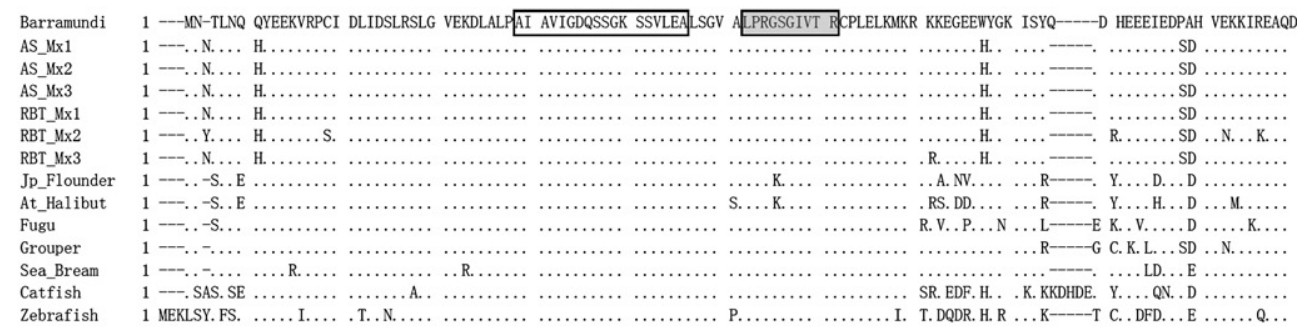

Barramundi 112 ENAGVGVGIS DDLISLEIAS PDVPDLTLID LPGIARVAVK GQPENIGEQI KRLIOKFIKR QETISLVVVP CNVDIATTEA LKMAQEVDPD GERTLGILTK PDVVDKGTEE TVVDIVHNEV

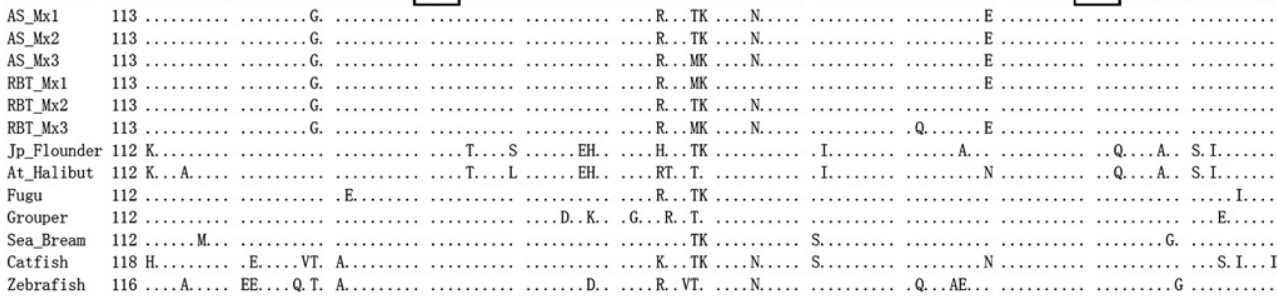

Barramundi 232 IHLKKGYMIV KCRGQKEITE KVSLTEAMER EKAFFQDHVH FHTLYNDGHA TVPKLAEKLT LELVHHIERS LPRLEEQIEE KLAQTQAEME RYGNGPPTDA AERLVYLIDK VTAFTQDAIN

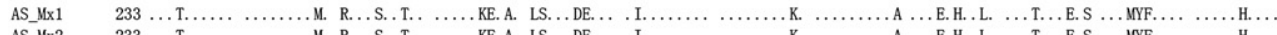

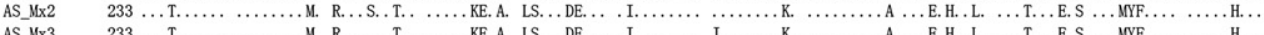

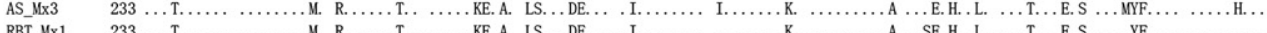

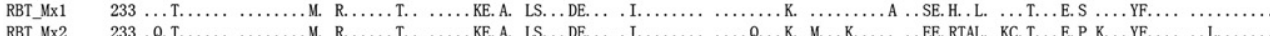

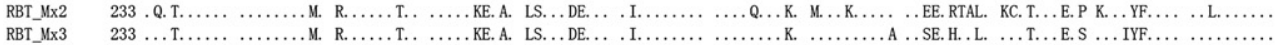

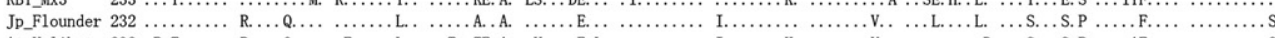

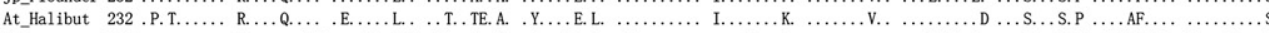

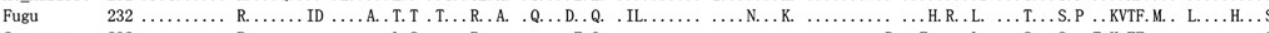

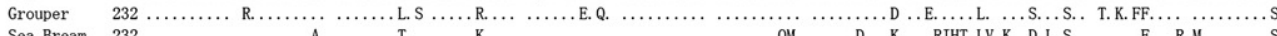

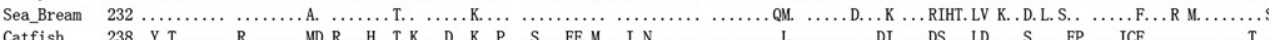

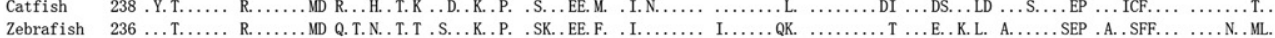

Barramundi 352 LAAGEELQCG DKLNVFSTLR REFGKWYSQL DHSGQNFNRR IDREVEEYEE RYRGRELPGF INYKTFEVMV KEQIKQLEEP AVKKLKDIGD AVRKAFVQLA HSSFIGFPNL MKTAKTKIEA

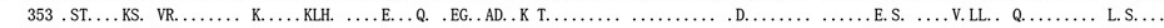

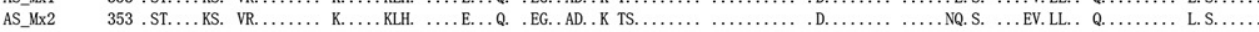

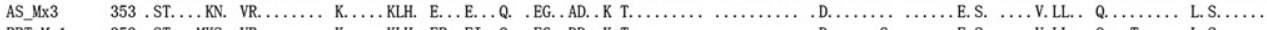

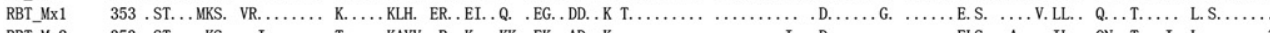

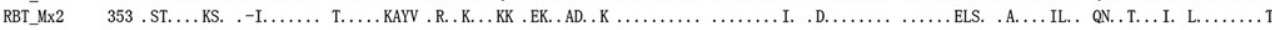

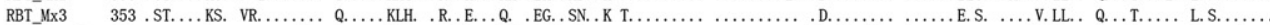

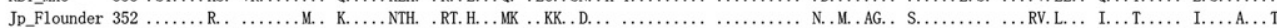

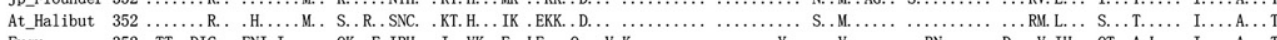

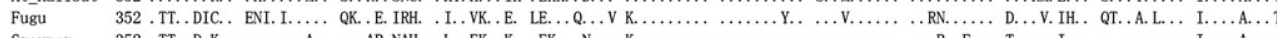

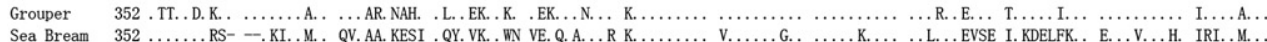

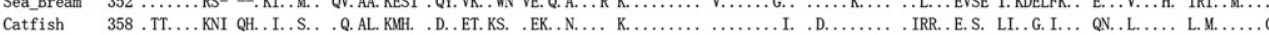

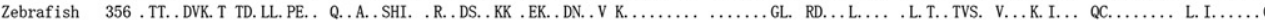

Barramundi 472 IKQEKESTAE STLRTQFKME MIVYSQDRTY SSSLSDRKRE EDEDE-- - LKCP KFNTKRSIVH CIDNHATLQE LMLHLKSYYS IASQRLADQI PIVIRYQMLQ ESAVQLOREM

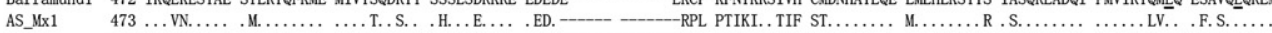

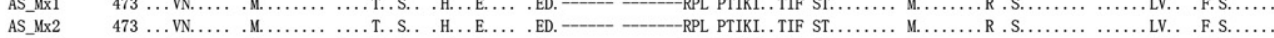

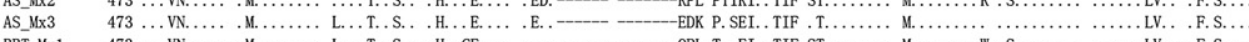
RBT_Mx1 $473 \ldots$ VN..... M. ...... L...T. .S. . . H. . CE... . .

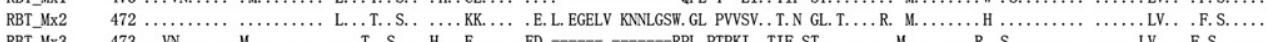

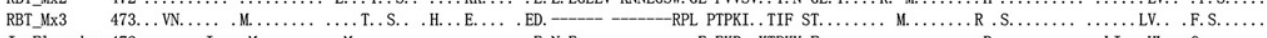

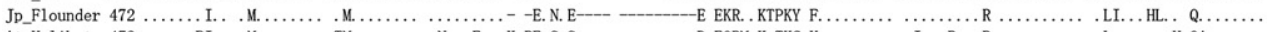

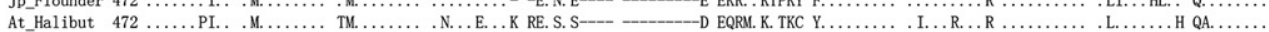

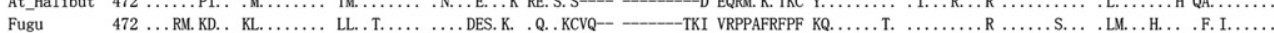

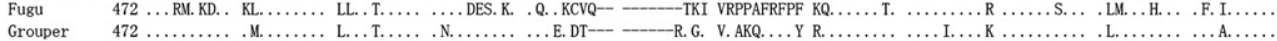

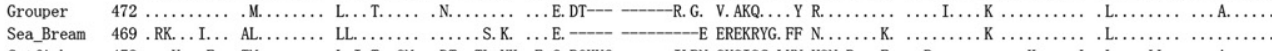

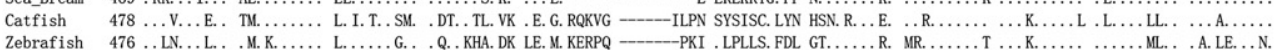

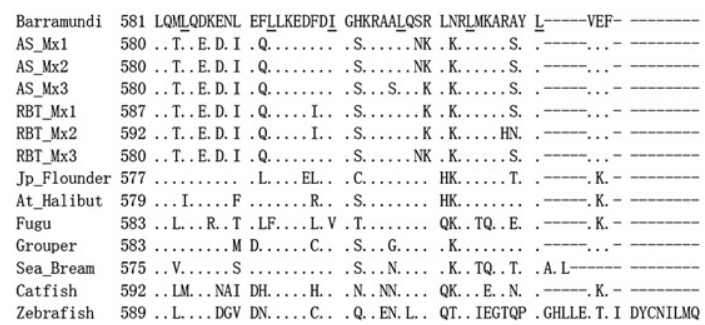

Fig. 1. Amino acid alignment of the barramundi Mx with other fish Mx sequences using Clustal W alignment program. Sequence identity is represented by dots and gaps are indicated as dashes. The empty boxes indicate the GTP-binding motif and the gray box indicates the dynamin family signature. The putative leucine zipper is depicted in the region by underlining leucine and isoleucine residues. 
Table 1

Comparison of sequence identity between barramundi Mx protein (Genebank accession number AY821518) and the Mx protein of other species

\begin{tabular}{llll}
\hline Species & NCBI accession no. & Protein region compared & $\%$ identity \\
\hline Atlantic Salmon Mx1 & U66475 & $1-624$ & 83 \\
Atlantic Salmon Mx2 & U66476 & $1-624$ & $1-624$ \\
Atlantic Salmon Mx3 & U66477 & $1-624$ & 83 \\
Rainbow Trout Mx1 & U30253 & $1-624$ & 83 \\
Rainbow Trout Mx2 & U47945 & $1-624$ & 80 \\
Rainbow Trout Mx3 & U47946 & $1-624$ & 83 \\
Japanese flounder & AB110446 & $1-624$ & 85 \\
Atlantic halibut & AF245513 & $1-624$ & 81 \\
Fugu & AF525215 & $1-624$ & 78 \\
Grouper & AY574372 & $1-623$ & 87 \\
Sea bream & AF491302 & $1-624$ & 81 \\
Catfish & AY095349 & $6-621$ & 73 \\
Zebrafish & AF533769 & $2-624$ & 70 \\
Human MxA & M30817 & $2-624$ & 56 \\
Human MxB & M30818 & $8-624$ & 52 \\
Mouse Mx1 & M21117 & $4-624$ & 51 \\
Rat Mx1 & X52711 &
\end{tabular}

\subsection{Induction of Mx expression by virus infection}

The cBB cells were infected with one of the following viruses: fish nodavirus (B00GD), birnavirus (IPNV-SP), or iridovirus (TGIV). After viral infection, time course expression of $\mathrm{Mx}$ in cBB cells was detected by real-time PCR. In nodavirus infection, Mx expression was elevated at $24 \mathrm{~h}$ post-infection (hpi) and remained at a high level until $72 \mathrm{hpi}$. In birnavirus and iridovirus infections, Mx expression could only be detected for 6 to 24 hpi when CPE had not appeared, and the levels of Mx expression were much lower than that induced by nodavirus infection. The level of Mx gene expression in nodavirus infection was 20- and 50-fold higher than those in birnavirus and iridovirus 24 hpi respectively (Fig. 4).

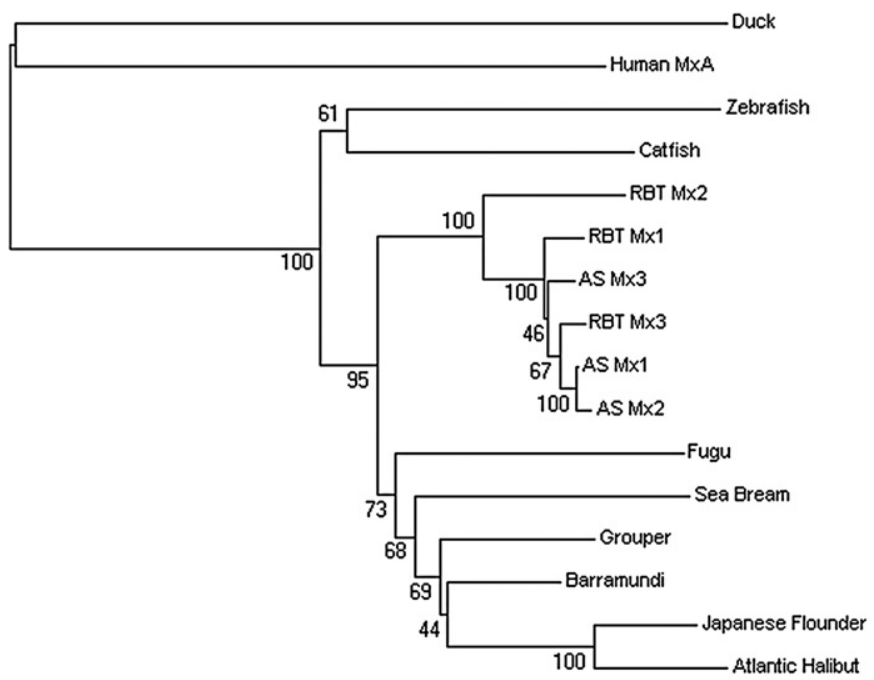

$$
\longmapsto 0.05
$$

Fig. 2. Mx protein phylogenetic tree. The amino acid alignment of Fig. 1 was used to construct a neighbor-joining tree of Mx protein. Bootstrap support values are given under the branches. 

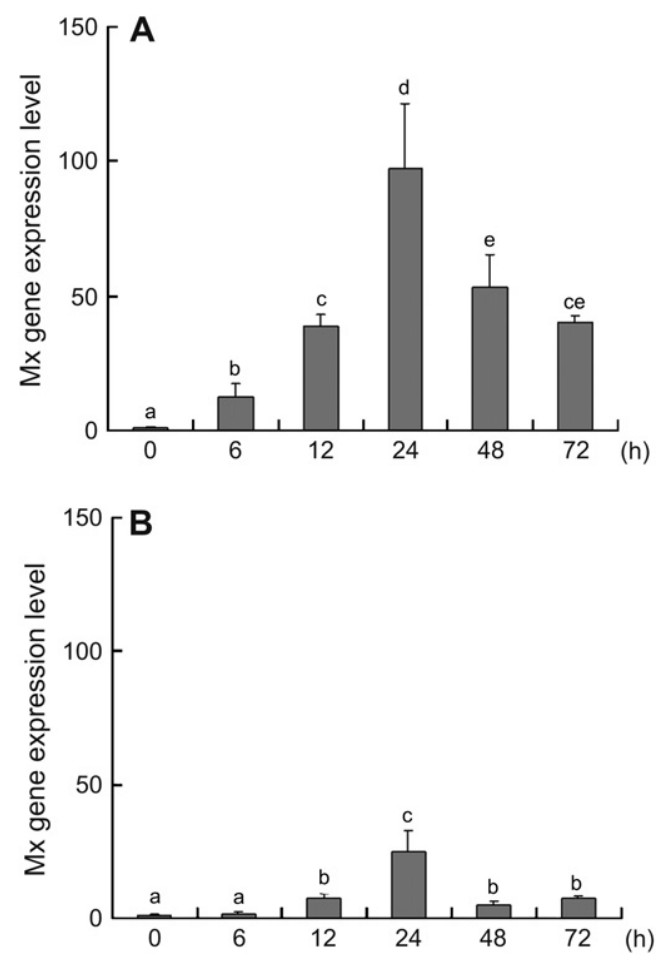

Fig. 3. Detection of Mx expression in cBB cells transfected with poly I:C at different incubation temperature by real-time PCR. The cBB cells were transfected with poly I:C $\left(1 \mu \mathrm{g} \mathrm{ml}^{-1}\right)$ and incubated at (A) $28^{\circ} \mathrm{C}$, and (B) $20^{\circ} \mathrm{C}$. Column bars with different letters are significantly different at $P<0.05(N=3)$.

\subsection{Antiviral activity of poly I:C-transfected cBB cells}

The IFN response including Mx expression was first induced in cBB cells by poly I:C transfection, and then the antiviral activity against three kinds of fish viruses was measured (Fig. 5). The optimal MOI for inducing complete $\mathrm{CPE}$ in cBB cells was different for each virus, 100 for nodavirus, 0.1 for birnavirus and 10 for iridovirus. Without poly $\mathrm{I}: \mathrm{C}$ transfection, the survival rate of $\mathrm{cBB}$ cells infected by fish nodavirus, birnavirus, and iridovirus infections were $2 \%, 0.4 \%$, and $18 \%$ respectively. With poly $\mathrm{I}: \mathrm{C}$ transfection, the survival rate of $\mathrm{cBB}$ cells infected by nodavirus and birnavirus infections significantly rose to $98.4 \%$ and $114.8 \%$ respectively, but there was no significant difference $(P>0.05)$ in the iridovirus-infected $\mathrm{cBB}$ cells which showed only a slight increase in the survival rate of cells (29.9\%). Therefore, poly I:C-transfected cBB cells showed antiviral activity against nodavirus and birnavirus, but not against iridovirus.

\subsection{The influence of Mx gene expression on the replication of fish virus}

The cBB cells were first transfected with siRNA to inhibit Mx gene expression, and then transfected with poly I:C to induce IFN response and the expression of antiviral genes except Mx gene in cBB cells. The result revealed that Mxspecific siRNA was able to inhibit about 75\% of Mx gene expression, compared with non-silencing siRNA (Fig. 6A). When non-silencing siRNA-transfected cBB cells were subsequently infected with three kinds of fish viruses, the viral replication level of nodavirus and birnavirus was decreased to $21 \%$ and $12.5 \%$ respectively. However, Mx-specific siRNA transfection of cBB cells caused a significant increase in the replication levels of nodavirus (68\%) and birnavirus (32\%), which were approximately 3 -fold higher than those in non-silencing siRNA-transfected cBB cells. On the other hand, the replication levels of iridovirus in cBB cells showed no significant differences $(P>0.05)$ between Mx-specific and non-silencing siRNA-transfected cBB cells (Fig. 6B,C,D). 

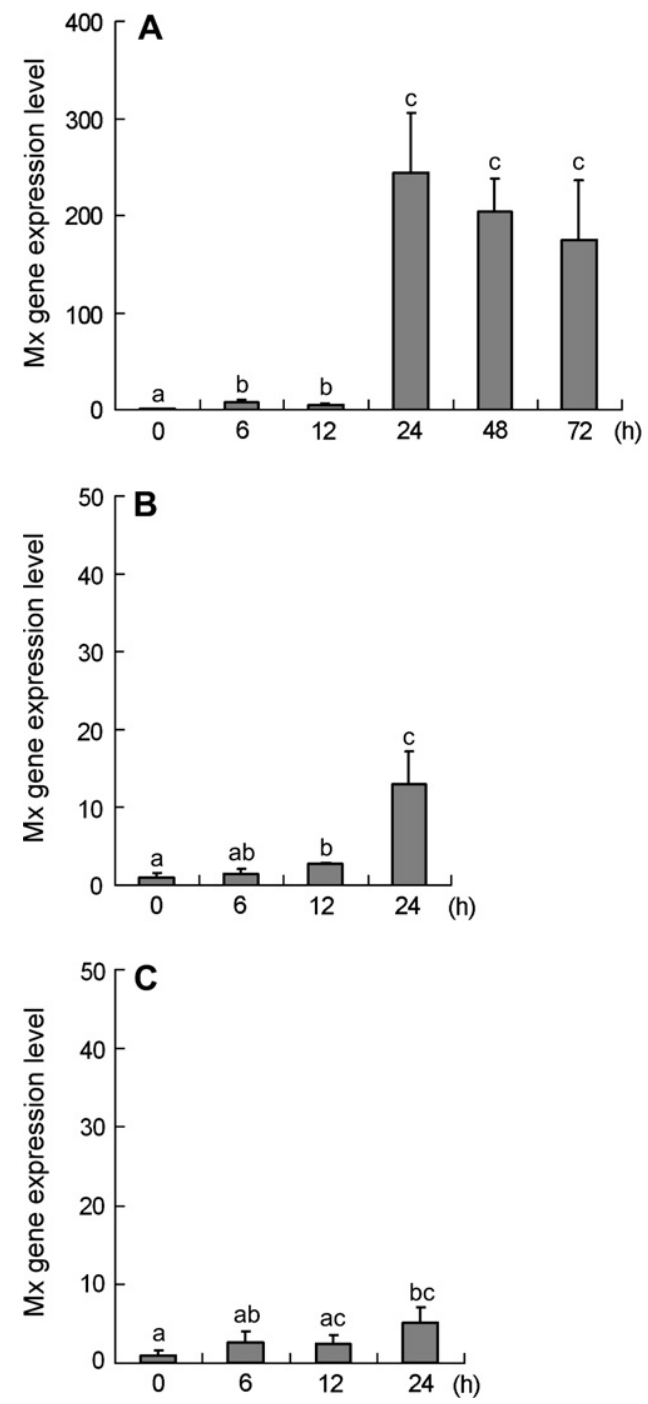

Fig. 4. Detection of Mx expression by real-time PCR in (A) Nodavirus-infected cBB cells, (B) Birnavirus-infected cBB cells, and (C) Iridovirusinfected cBB cells. Column bars with different letters are significantly different at $P<0.05(N=3)$.

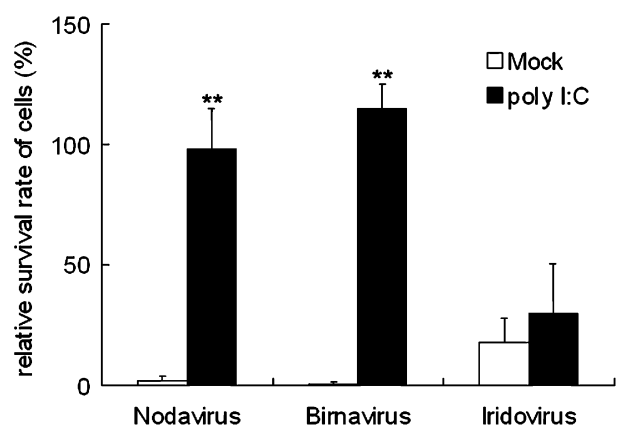

Fig. 5. Antiviral activity in poly I:C-transfected cBB cells against 3 kinds of fish viruses. The cBB cells were transfected with poly I:C (black bar) or not (white bar). After $24 \mathrm{~h}$ treatment, cells were washed with PBS and then infected with one of the following: nodavirus, birnavirus, or iridovirus. The $\mathrm{OD}_{595}$ values of all wells were measured by crystal violet staining when complete CPE appeared in the cells without poly I:C transfection. Results were presented as the percentage of surviving cells, calculated as the $\mathrm{OD}_{595}$ of infected cells $(n=4)$ divided by the $\mathrm{OD}_{595}$ of cells with neither treatment nor viral infection. Bars represent standard deviations. $* * P<0.01$. 

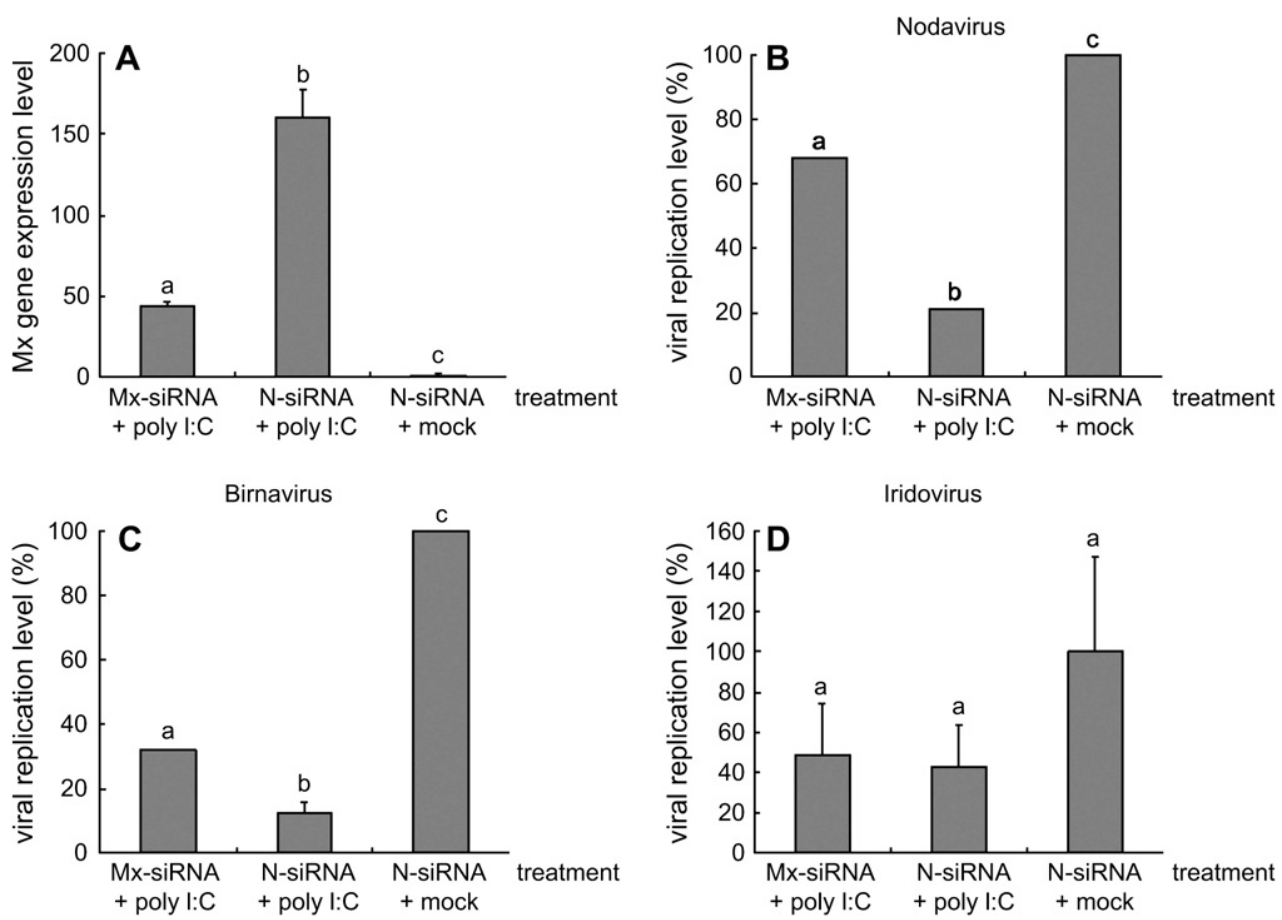

Fig. 6. The influence of Mx gene expression on viral replication. (A) Mx gene expression in cBB cells was inhibited by specific siRNA. The cBB cells were pre-transfected with Mx-specific siRNA (Mx-siRNA) to inhibit Mx gene expression; non-silencing siRNA (N-siRNA) was used as negative control. After $4 \mathrm{~h}$ incubation, cells were transfected with poly I:C, and the level of Mx gene expression was detected by real-time PCR $18 \mathrm{~h}$ later. Thereafter, the treated cells were infected with (B) Nodavirus, (C) Birnavirus, (D) Iridovrus. The cells were harvested $24 \mathrm{~h}$ post-infection, and the progeny virus was titrated. Viral titer was presented as the percentage of viral replication level (viral titer from any treated cells/viral titer from non-poly I:C-transfected cells). The mean viral titers given are the average of three independent experiments. Error bars indicate standard deviations. Repeated experiments which have the same results will lack the standard deviations. Column bars with different letters are significantly different at $P<0.05(N=3)$.

\section{Discussion}

In this study, a cDNA clone of barramundi Mx gene was constructed from the extracted mRNA of cBB cells after NNV infection. The motif characteristics of Mx proteins, including the GTP-binding site, the dynamin family signature, and the leucine zipper are all present in barramundi Mx. GTP-binding motif is important for antiviral activity because GTP binding induces a conformational change of the Mx protein that allows specific recognition of viral targets [34]. Mutations in the GTP-binding domain resulted in loss of antiviral activity [35]. The dynamin family signature is found in all members of the dynamin family that is essential for receptor-mediated endocytosis and synaptic vesicle recycling [36]. The leucine zipper is a region for protein-protein interaction and is thought to play a role in the oligomerisation for antiviral activity [37].

Poly I:C, an artificial double-stranded RNA, can induce Mx expression in vivo and in vitro. Many kinds of fish species had been injected with poly I:C for induction of Mx gene expression [16-18,21-23,38]. In vitro, Mx gene expression could also be induced by poly I:C in some fish cell lines, such as RTG-2 cells [16], CHSE-214 [39], SAF-1 [21], and CCO cells [22]. In this study, cBB cells expressed Mx gene by poly I:C transfection either at $28{ }^{\circ} \mathrm{C}$ or $20^{\circ} \mathrm{C}$, but the expression level of $\mathrm{Mx}$ at $20^{\circ} \mathrm{C}$ was lower and delayed compared to that at $28{ }^{\circ} \mathrm{C}$, which was an optimal culture temperature for barramundi. It might be that lower temperature resulted in slower growth and gene expression. Although Mx gene expression abated at low temperature, it could still be turned on by poly I:C.

Mx induction by fish viruses has been reported in many cases, including channel catfish virus (CCV) in catfish [22], nodavirus and iridovirus in grouper [23], infectious hematopoietic necrosis virus (IHNV) in rainbow trout [16], IPNV in Atlantic halibut [18], hirame rhabdovirus (HIRRV) or aquabirnavirus in Japanese flounder [19,40] in vivo, and 
nodavirus in SAF-1 cells [21] in vitro. In the present study, we found that cBB cells were sensitive to nodavirus, birnavirus and iridovirus infection. High MOI (10) was used for synchronous virus infection in the time-course experiment. The Mx expression in response to fish nodavirus in cBB cells was elevated to high levels from 24 to $72 \mathrm{hpi}$ (the last sampling time point). However, the level of Mx gene expression in response to fish birnavirus and iridovirus in cBB cells was much lower than that in nodavirus-infected cBB cells, and could only be detected from 6 to 24 hpi. It was also observed that complete CPE appeared in birnavirus- and iridovirus-infected cBB cells within 2 days, but in nodavirus-infected cBB cells, it was delayed until 14 days post-infection. Although the beginning of nodavirus replication is earlier than the expression of $\mathrm{Mx}$ gene in nodavirus-infected cBB cells, the increased expression of Mx gene after 24 hpi was enough to interfere with NNV replication and delay CPE.

Although low MOI (0.01) was applied for birnavirus infection of cBB cells, half of the cells exhibited CPE within $48 \mathrm{hpi}$, and the level of Mx expression were still as low as that with high MOI (10) (data not shown). Two hypotheses were suggested to explain the rapid appearance of CPE in birnavirus- or iridovirus-infected cBB cells. One is that birnavirus or iridovirus infection might suppress cellular gene expression, and the second possibility is the lack of specific Toll-like receptors (TLR) for recognizing birna- or iridovirus nucleic acids. It had been reported that IPNV could suppress type I interferon signaling [41], and FV3, frog iridovirus, could down-regulate cellular macromolecular synthesis [42]. The low level expression of Mx gene in birnavirus- and iridovirus-infected cBB cells might be due to the inhibition of cellular gene expression, including Mx expression or IFN-related gene expression, or macromolecular synthesis during viral infection. Therefore, in the absence of cellular defense, these viruses can proliferate more successfully, and cause CPE within $48 \mathrm{~h}$ in cBB cells. Nodavirus is single-stranded sense RNA virus, birnavirus is double-stranded RNA virus, and iridovirus is double-stranded DNA virus. It has been reported that viral dsRNA and poly I:C can be recognized by TLR3; while, viral ssRNA is recognized by TLR7 and TLR8, and viral or bacterial unmethylated CpG DNA motifs are recognized by TLR9 [43]. Therefore, the low level expression of Mx gene in birnavirus- and irodovirus-infected cBB cells might be due to the lack of TLR3 and TLR9. In our previous study, we observed that $\mathrm{Mx}$ gene expression in cBB cells is only induced by poly I:C-transfection but not by poly I:C-incubation, suggesting that cBB cells might lack TLR3 [30]. Additionally, some viral glycoproteins are reported to be able to elicit an IFN response [44-48]. Thus, the glycosylated capsid protein of nodavirus might also be potent in inducing an IFN response in cBB cells.

Antiviral activity had been shown in human MxA [49], rat Mx1, Mx2 [50], mouse Mx1 [13,51], Mx2 [14,52], porcine Mx1 [53], chicken Mx [54], Japanese flounder Mx [24], and Atlantic salmon Mx1 [25], but not in human MxB, duck Mx and rat Mx3 [55]. In addition, the antiviral activity of Mx protein has been shown to be virus specific. For example, mouse $\mathrm{Mx} 2$ could inhibit vesicular stomatitis virus (VSV), but not influenza virus [14]. Moreover, we found that poly I:C could induce high level Mx expression in cBB cells $24 \mathrm{~h}$ post-transfection, and the transfected cBB cells showed very high antiviral activity against fish nodavirus and birnavirus, but not against fish iridovirus. Therefore, it is suggested that antiviral activity of barramundi Mx is virus-specific, and barramundi Mx has a role in protecting the cells from nodavirus- and birnavirus-induced cell lysis.

Here, we have further demonstrated that Mx-specific siRNAs could down-regulate Mx expression in the treated cBB cells. However, the levels of nodavirus and birnavirus replication in the treated cBB cells were only restored to $68 \%$ and $32 \%$ respectively. One possibility is that other IFN-induced antiviral proteins were also involved in the inhibition of nodavirus and birnavirus replication. Another possibility is that a low level of Mx gene was still expressed, and inhibited the nodavirus and birnavirus replication. In the present study, six clones of barramundi Mx cDNA had been sequenced and compared, but all the sequences were the same (data not shown). Whether there are more than one form of barramundi Mx genes needs further study. In the future, we will find an NNV-permissive cell line without Mx gene, and transfect it with barramundi Mx cDNA to determine whether a certain form of barramundi Mx is responsible for the anti-nodavirus or anti-birnavirus activities.

\section{Acknowledgements}

The authors would like to thank Dr. Oystein Evensen for providing IPNV-Sp isolate and Dr. Chou H.Y. for providing TGIV isolate. This work is financially supporting by the National Science Council of the Republic of China under the Contract No. NSC 94-2311-B-002-024. 


\section{References}

[1] Samuel CE. Antiviral action of interferons. Clin Microbiol Rev 2001;14:778-809.

[2] Staeheli P. Interferon-induced proteins and the antiviral state. Adv Virus Res 1990;38:147-200.

[3] Pitossi F, Blank A, Schroder A, Schwarz A, Hussi P, Schwemmle M, et al. A functional GTP-binding motif is necessary for antiviral activity of Mx proteins. J Virol 1993;67:6726-32.

[4] Lindenmann J. Resistance of mice to mouse-adapted influenza A virus. Virology 1962;16:203-4.

[5] Aebi M, Fah J, Hurt N, Samuel CE, Thomis D, Bazzigher L, et al. cDNA structures and regulation of two interferon-induced human Mx proteins. Mol Cell Biol 1989;9:5062-72.

[6] Muller M, Winnacker EL, Brem G. Molecular cloning of porcine Mx cDNAs: new members of a family of interferon-inducible proteins with homology to GTP-binding proteins. J Interferon Res 1992;12:119-29.

[7] Charleston B, Stewart HJ. An interferon-induced Mx protein: cDNA sequence and high-level expression in the endometrium of pregnant sheep. Gene 1993;137:327-31.

[8] Ellinwood NM, McCue JM, Gordy PW, Bowen RA. Cloning and characterization of cDNAs for a bovine (Bos taurus) Mx protein. J Interferon Cytokine Res 1998;18:745-55.

[9] Bazzigher L, Schwarz A, Staeheli P. No enhanced influenza virus resistance of murine and avian cells expressing cloned duck Mx protein. Virology 1993;195:100-12.

[10] Bernasconi D, Schultz U, Staeheli P. The interferon-induced Mx protein of chickens lacks antiviral activity. J Interferon Cytokine Res $1995 ; 15: 47-53$

[11] Nakayama M, Nagata K, Kato A, Ishihama A. Interferon-inducible mouse Mx1 protein that confers resistance to influenza virus is GTPase. J Biol Chem 1991;266:21404-8.

[12] Schneider-Schaulies S, Schneider-Schaulies J, Schuster A, Bayer M, Pavlovic J, ter Meulen V. Cell type-specific MxA-mediated inhibition of measles virus transcription in human brain cells. J Virol 1994;68:6910-7.

[13] Thimme R, Frese M, Kochs G, Haller O. Mx1 but not MxA confers resistance against tick-borne Dhori virus in mice. Virology 1995;211:296-301.

[14] Zurcher T, Pavlovic J, Staeheli P. Mouse Mx2 protein inhibits vesicular stomatitis virus but not influenza virus. Virology 1992;187:796-800.

[15] Staeheli P, Yu YX, Grob R, Haller O. A double-stranded RNA-inducible fish gene homologous to the murine influenza virus resistance gene Mx. Mol Cell Biol 1989;9:3117-21.

[16] Trobridge GD, Leong JA. Characterization of a rainbow trout Mx gene. J Interferon Cytokine Res 1995;15:691-702.

[17] Robertsen B, Trobridge G, Leong JA. Molecular cloning of double-stranded RNA inducible Mx genes from Atlantic salmon (Salmo salar L.). Dev Comp Immunol 1997;21:397-412.

[18] Jensen V, Robertsen B. Cloning of an Mx cDNA from Atlantic halibut (Hippoglossus hippoglossus) and characterization of Mx mRNA expression in response to double-stranded RNA or infectious pancreatic necrosis virus. J Interferon Cytokine Res 2000;20:701-10.

[19] Lee JY, Hirono I, Aoki T. Cloning and analysis of expression of Mx cDNA in Japanese flounder, Paralichthys olivaceus. Dev Comp Immunol 2000;24:407-15.

[20] Yap WH, Tay A, Brenner S, Venkatesh B. Molecular cloning of the pufferfish (Takifugu rubripes) Mx gene and functional characterization of its promoter. Immunogenetics 2003;54:705-13.

[21] Tafalla C, Aranguren R, Secombes CJ, Figueras A, Novoa B. Cloning and analysis of expression of a gilthead sea bream (Sparus aurata) Mx cDNA. Fish Shellfish Immunol 2004;16:11-24.

[22] Plant KP, Thune RL. Cloning and characterisation of a channel catfish (Ictalurus punctatus) Mx gene. Fish Shellfish Immunol 2004; 16:391-405.

[23] Chen YM, Su YL, Lin JH, Yang HL, Chen TY. Cloning of an orange-spotted grouper (Epinephelus coioides) Mx cDNA and characterisation of its expression in response to nodavirus. Fish Shellfish Immunol 2006;20:58-71.

[24] Caipang CM, Hirono I, Aoki T. In vitro inhibition of fish rhabdoviruses by Japanese flounder, Paralichthys olivaceus Mx. Virology 2003;317:373-82.

[25] Larsen R, Rokenes TP, Robertsen B. Inhibition of infectious pancreatic necrosis virus replication by Atlantic salmon Mx1 protein. J Virol 2004;78:7938-44.

[26] Chi SC, Shieh JR, Lin SJ. Genetic and antigenic analysis of betanodaviruses isolated from aquatic organisms in Taiwan. Dis Aquat Organ 2003;55:221-8.

[27] Chou HY, Hsu CC, Peng TY. Isolation and characterization of a pathogenic iridovirus from cultured grouper (Epinephelus Sp.) in Taiwan. Fish Pathol 1998;33:201-6.

[28] Johansen R, Amundsen M, Dannevig BH, Sommer AI. Acute and persistent experimental nodavirus infection in spotted wolffish Anarhichas minor. Dis Aquat Organ 2003;57:35-41.

[29] Chi SC, Wu YC, Cheng TM. Persistent infection of betanodavirus in a novel cell line derived from the brain tissue of barramundi Lates calcarifer. Dis Aquat Organ 2005;65:91-8.

[30] Wu YC, Chi SC. Persistence of betanodavirus in Barramundi brain (BB) cell line involves the induction of Interferon response. Fish Shellfish Immunol 2006;21:540-7.

[31] Chi SC, Hu WW, Lo BJ. Establishment and characterization of a continous cell line (GF-1 cell line) derived from grouper Epinephelus coioides (Hamilton): a cell line susceptible to grouper nervous necrosis virus (GNNV). J Fish Dis 1999;22:1-10.

[32] Chomczynski P, Sacchi N. Single-step method of RNA isolation by acid guanidinium thiocyanate-phenol-chloroform extraction. Anal Biochem 1987;162:156-9. 
[33] Kumar S, Tamura K, Nei M. MEGA3: integrated software for molecular evolutionary genetics analysis and sequence alignment. Brief Bioinform 2004;5:150-63.

[34] Kochs G, Haller O. GTP-bound human MxA protein interacts with the nucleocapsids of Thogoto virus (Orthomyxoviridae). J Biol Chem 1999;274:4370-6.

[35] Melen K, Julkunen I. Mutational analysis of murine Mx1 protein: GTP binding core domain is essential for anti-influenza A activity. Virology 1994;205:269-79.

[36] Urrutia R, Henley JR, Cook T, McNiven MA. The dynamins: redundant or distinct functions for an expanding family of related GTPases? Proc Natl Acad Sci USA 1997;94:377-84.

[37] Ponten A, Sick C, Weeber M, Haller O, Kochs G. Dominant-negative mutants of human MxA protein: domains in the carboxy-terminal moiety are important for oligomerization and antiviral activity. J Virol 1997;71:2591-9.

[38] Jensen I, Albuquerque A, Sommer AI, Robertsen B. Effect of poly I:C on the expression of Mx proteins and resistance against infection by infectious salmon anaemia virus in Atlantic salmon. Fish Shellfish Immunol 2002;13:311-26.

[39] Jensen I, Larsen R, Robertsen B. An antiviral state induced in Chinook salmon embryo cells (CHSE-214) by transfection with the doublestranded RNA poly I:C. Fish Shellfish Immunol 2002;13:367-78.

[40] Pakingking Jr R, Okinaka Y, Mori K, Arimoto M, Muroga K, Nakai T. In vivo and in vitro analysis of the resistance against viral haemorrhagic septicaemia virus in Japanese flounder (Paralichthys olivaceus) precedingly infected with aquabirnavirus. Fish Shellfish Immunol 2004;17:1-11.

[41] Collet B, Munro ES, Gahlawat S, Acosta F, Garcia J, Roemelt C, et al. Infectious pancreatic necrosis virus suppresses type I interferon signalling in rainbow trout gonad cell line but not in Atlantic salmon macrophages. Fish Shellfish Immunol 2007;22(1-2):44-56.

[42] Williams T, Barbosa-Solomieu V, Chinchar VG. A decade of advances in iridovirus research. Adv Virus Res 2005;65:173-248.

[43] Robertsen B. The inferferon system of teleost fish. Fish Shellfish Immunol 2006;20:172-91.

[44] Lebon P. Inhibition of herpes simplex virus type-1 induced interferon synthesis by monoclonal antibodies against viral glycoprotein D and by lysosomotropic drugs. J Gen Virol 1985;66:2781-6.

[45] Charley B, Laude H. Induction of alpha interferon by transmissible gastroenteritis coronavirus: role of transmembrane glycoprotein E1 J Virol 1988;62:8-11.

[46] Charley B, Levenant L, Delmas B. Glycosylation is required for coronavirus TGEV to induce an efficient production of IFN a by blood mononuclear cells. Scand J Immunol 1991;33:435-40.

[47] Boehme KW, Singh J, Perry ST, Compton T. Human cytomegalovirus elicits a coordinated cellular antiviral response via envelope glycoprotein B. J Virol 2004;78:1202-11.

[48] Acosta F, Collet B, Lorenzen N, Ellis AE. Expression of the glycoprotein of viral haemorrhagic septicaemia virus (VHSV) on the surface of the fish cell line RTG-P1 induces type 1 interferon expression in neighbouring cells. Fish Shellfish Immunol 2006;21:272-8.

[49] Pavlovic J, Zurcher T, Haller O, Staeheli P. Resistance to influenza virus and vesicular stomatitis virus conferred by expression of human MxA protein. J Virol 1990;64:3370-5.

[50] Meier E, Kunz G, Haller O, Arnheiter H. Activity of rat Mx proteins against a rhabdovirus. J Virol 1990;64:6263-9.

[51] Haller O, Frese M, Rost D, Nuttall PA, Kochs G. Tick-borne thogoto virus infection in mice is inhibited by the orthomyxovirus resistance gene product Mx1. J Virol 1995;69:2596-601.

[52] Jin HK, Yoshimatsu K, Takada A, Ogino M, Asano A, Arikawa J, et al. Mouse Mx2 protein inhibits hantavirus but not influenza virus replication. Arch Virol 2001;146:41-9.

[53] Asano A, Ko JH, Morozumi T, Hamashima N, Watanabe T. Polymorphisms and the antiviral property of porcine Mx1 protein. J Vet Med Sci 2002;64:1085-9.

[54] Ko JH, Jin HK, Asano A, Takada A, Ninomiya A, Kida H, et al. Polymorphisms and the differential antiviral activity of the chicken Mx gene. Genome Res 2002;12:595-601.

[55] Lee SH, Vidal SM. Functional diversity of Mx proteins: variations on a theme of host resistance to infection. Genome Res 2002;12:527-30. 